\title{
The impact of environmental metals in young urbanites' brains
}

\author{
Lilian Calderón-Garcidueñas, MD PhD ${ }^{1,2}$, Alejandro Serrano-Sierra, MD ${ }^{1}$, Ricardo Torres- \\ Jardón, $\mathrm{PhD}^{3}$, Hongtu Zhu, $\mathrm{PhD}^{4}$, Ying Yuan, $\mathrm{PhD}^{4}$, Donna Smith, BS $^{2}$, Ricardo Delgado- \\ Chávez, MD ${ }^{5}$, Janet V. Cross, $\mathrm{PhD}^{6}$, Humberto Medina- Cortina, $\mathrm{MD}^{1}$, Michael Kavanaugh, \\ $\mathbf{P h D}^{2}$, and Tomás R. Guilarte, $\mathbf{P h D}^{7}$ \\ ${ }^{1}$ Instituto Nacional de Pediatría, Mexico City, Mexico 04530 \\ 2 The Center for Structural and Functional Neurosciences, The University of Montana, Missoula, \\ MT, USA 59812 \\ ${ }^{3}$ Centro de Ciencias de la Atmósfera, Universidad Nacional Autónoma de México, Mexico City, \\ Mexico 04510 \\ ${ }^{4}$ Biostatistics, University of North Carolina Gillings School of Global Public Health, Chapel Hill, \\ NC, 27599, USA \\ 5 Instituto Nacional de Cancerología, Mexico City, Mexico 04330 \\ ${ }^{6}$ Department of Pathology, University of Virginia School of Medicine, Charlottesville, VA 22908 \\ ${ }^{7}$ Environmental Health Sciences, Mailman School of Public Health, Columbia University, NY, NY \\ 10032
}

\section{Abstract}

Air pollution exposures are linked to cognitive and olfaction deficits, oxidative stress, neuroinflammation and neurodegeneration including frontal hyperphosphorilated tau and diffuse amyloid plaques in Mexico City children and young adults. Mexico City residents are chronically exposed to fine particulate matter $\left(\mathrm{PM}_{2.5}\right)$ concentrations (containing toxic combustion and industrial metals) above the annual standard $\left(15 \mu \mathrm{g} / \mathrm{m}^{3}\right)$ and to contaminated water and soil. Here, we sought to address the brain-region-specific effects of metals and key neuroinflammatory and DNA repair responses in two air pollution targets: frontal lobe and olfactory bulb from 12 controls v 47 Mexico City children and young adults average age $33.06 \pm 4.8$ SE years. Inductively coupled plasma mass spectrometry (metal analysis) and real time PCR (for COX2, IL1 $\beta$ and DNA repair genes) in target tissues. Mexico City residents had higher concentrations of metals associated with PM: manganese $(\mathrm{p}=0.003)$, nickel and chromium $(\mathrm{p}=0.02)$ along with higher frontal COX2 mRNA ( $\mathrm{p}=0.008)$ and $\operatorname{IL} 1 \beta(\mathrm{p}=0.0002)$ and $\operatorname{COX} 2(\mathrm{p}=0.005)$ olfactory bulb indicating neuroinflammation. Frontal metals correlated with olfactory bulb DNA repair genes and with frontal and hippocampal inflammatory genes. Frontal manganese, cobalt and selenium increased with age in exposed subjects.

Together, these findings suggest PM-metal neurotoxicity causes brain damage in young urbanites, the olfactory bulb is a target of air pollution and participates in the neuroinflammatory response

(C) 2012 Elsevier GmbH. All rights reserved.

Corresponding author: Lilian Calderón-Garcidueñas MD PhD The Center for Structural and Functional Neurosciences, The University of Montana, 32 Campus Drive, 289 Skaggs Bldg. Missoula MT 59812, Phone 406-243-4785, Fax 406-243-2807 lilian.calderon-garciduenas@umontana.edu.

Publisher's Disclaimer: This is a PDF file of an unedited manuscript that has been accepted for publication. As a service to our customers we are providing this early version of the manuscript. The manuscript will undergo copyediting, typesetting, and review of the resulting proof before it is published in its final citable form. Please note that during the production process errors may be discovered which could affect the content, and all legal disclaimers that apply to the journal pertain. 
and since metal concentrations vary significantly in Mexico City urban sub-areas, place of residency has to be integrated with the risk for CNS detrimental effects particularly in children.

\section{Keywords}

Air pollution; children; DNA repair; frontal; humans; lungs; megacities; metals; manganese; olfactory bulb; fine particulate matter $\mathrm{PM}_{2.5}$

\section{Introduction}

Air pollution is a complex mixture of particulate matter (PM), gases, organic and inorganic compounds present in outdoor and indoor air. Children living in Mexico City (MC) exhibit evidence of chronic inflammation of the upper and lower respiratory tracts, accumulation of ultrafine PM in nasal respiratory epithelium, breakdown of the nasal respiratory epithelial barrier, systemic inflammation, immunodysregulation, brain inflammation, cognitive and olfaction deficits, and brain magnetic resonance imaging (MRI) structural abnormalities (Calderón-Garcidueñas et al. 2001a,b, 2003a,b, 2004, 2007, 2008a,b,c, 2009, 2010,2011a,c; Block and Calderón-Garcidueñas 2009). Children and adults exhibit up-regulation of inflammation-associated genes including cyclooxygenase-2 (COX2), interleukin 1 beta (IL-1 $\beta$ ), and the key innate immunity receptor CD14 in their olfactory bulbs, frontal cortex, substantia nigra and vagus nerve (Calderón-Garcidueñas et al. 2004, 2008b). The frontal cortex of $40 \%$ of children and young adults age $18.37 \pm 6.9$ years resident in Mexico City exhibited tau hyperphosphorylation with pre-tangle material and $51 \%$ had $\mathrm{A} \beta$ diffuse plaques compared with $0 \%$ in controls ( $21.8 \pm 10.8$ years) (Calderón-Garcidueñas et al. 2011b). Data from the same cohorts showed a significant up-regulation of gene network clusters including IL1, NF- $\times$ B, TNF, IFN and TLRs, along with a 15 fold frontal downregulation of the cellular prion protein $\left(\mathrm{PrP}^{\mathrm{C}}\right)$ in $\mathrm{MC}$ subjects (Calderón-Garcidueñas et al. 2011b). Our findings suggest that chronic exposure to severe urban air pollution causes a significant imbalance in genes essential for cell proliferation, apoptosis, oxidative stress, inflammation, innate and adaptive immune responses and early Alzheimer's disease-related pathological processes leading to neurofibrillary tangle formation start early in childhood or in early young adulthood. Moreover, clinically healthy Mexico City children performed more poorly across a variety of cognitive tests and had significant differences in white matter volumes compared to children from low polluted areas (Calderón-Garcidueñas et al. 2011c). Thus, exposures to urban pollution also perturb the trajectory of cerebral development (Calderón-Garcidueñas et al. 2011c).

Air pollution in Mexico City is severe and metals are an important component of urban particulate matter (Bravo-Alvarez and Torres-Jardón 2002; Chow et al. 2002; Molina and Molina 2004; Molina et al. 2007; Moreno et al. 2008; Rauch et al. 2006; Moffet et al. 2008; Querol et al. 2008; Guzmán-Morales et al. 2011). There is a significant heterogeneity in particle mass, composition and toxicity in $\mathrm{PM}_{10}$ (particulate matter $<10 \mu \mathrm{m}$ in diameter) samples collected in Mexico City (Rosas-Pérez et al. 2007). Further, the biological effects of $\mathrm{PM}_{10}$ using in vitro tests vary according to the regions within the city from where they were collected (Alfaro-Moreno et al. 2002, 2007).

There is an extensive literature associating health effects with ambient particulate matter and its components (Aschner et al. 2007; Maier et al. 2008; Happo et al. 2008; Chen et al. 2009), and studies addressing mechanisms that mediate PM metals toxicology (Ayres et al. 2008; Kodavanti et al. 2008; Nong et al. 2008; Tang et al. 2009; Frick et al. 2011). Accumulation of metal ions in the brain contributes to heightened oxidative stress and neuronal damage (Zatta et al. 2008; Bolognin et al. 2009). 
The goals of the present study were as follows: First, we set out to determine, using inductively coupled plasma mass spectrometry (ICP-MS), the content of metals associated with anthropogenic activities as well as essential metals and trace minerals related to normal brain function ( $\mathrm{V}, \mathrm{Ni}, \mathrm{Mn}, \mathrm{Pb}, \mathrm{Cr}, \mathrm{Fe}, \mathrm{Zn}, \mathrm{Se}, \mathrm{Cu}, \mathrm{Co}$ ) in frontal cortex and in the lungs from subjects residing in high- versus low-pollution areas. A second goal was to investigate if there was an association between the metal content in the frontal cortex and the lungs and gene expression of two inflammatory genes: COX 2 and IL1 $\beta$ that have proven to be good markers of exposure to urban air pollution (Calderón-Garcidueñas et al. 2003b, 2004, 2008a, 2011b; Villarreal-Calderon et al. 2010). Thirdly, since the olfactory bulb (OB) is a target and a portal of entry of air pollution components (Ali et al., 2010),we explored the relationship between frontal cortex metal concentrations and OB inflammatory and DNA repair gene responses. Finally, we assessed whether age is related to frontal cortex metal accumulation. Oxidative stress, neuroinflammation, and neurodegeneration are present early in life upon exposure to polluted megacities and environmental exposure to metals could play a critical role for the induction of inflammatory and DNA repair responses in the brain.

\section{Materials and Methods}

\section{Study cities and air quality data}

We selected a polluted megacity and two control cities. Mexico City (MC) was the selected megacity, while Tlaxcala and Veracruz were the low polluted cities. Mexico City represents an extreme of urban growth and environmental pollution (Bravo-Alvarez and Torres-Jardón 2002; Molina et al. 2007). The Mexico City Metropolitan Area lies in an elevated basin at an altitude of 2240 meters above mean sea level and its urbanized area covers around 2000 $\mathrm{km}^{2}$. The basin is surrounded by high mountain ridges on the east, south, and west but with a broad opening to the north and a gap to the south-southwest. The surrounding mountains combined with the frequent morning thermal inversions contribute to the trapping and accumulation of air pollutants inside the basin. In this geographical setting, 20 million residents, nearly 4 million vehicles, and over 40000 industries consume more than 40 million liters of petroleum fuels per day emitting significant concentrations of primary air pollutants (Molina et al. 2007). The high altitude and tropical climate of the region is highly conducive to fast photochemistry forming secondary pollutants such as ozone $\left(\mathrm{O}_{3}\right)$ and fine particulate matter $\left(\mathrm{PM}_{2.5}\right)$.

Control Cities-Tlaxcala and Veracruz were selected as the control cities due to their smaller size, low emission sources from industry and cars, and good ventilation conditions. Three additional factors for the selection of the control cities included: i. altitude above sea level similar to Mexico City (i.e., Tlaxcala), ii. dog pathology studies from these cities have shown minimal pathology in lungs and hearts (Calderón-Garcidueñas et al. 2001a), and iii.clinical studies in these cities that have shown healthy children with no evidence of air pollution-associated pathology (Calderón-Garcidueñas et al. 2003a).

\section{Autopsy population selection}

The study protocol was approved by the Institutional Review Boards for Human Studies at the involved Institutions. We studied 59 subjects from 2 cohorts of children and adults, ages 2-87 years, with an average age of $33.06 \pm 4.8 \mathrm{y}$. The control cohort included subjects from low polluted cities (n: 12), and the exposed cohort (n: 47) from MC. The 59 subjects had complete autopsies and neuropathology examinations, and were included in the real time polymerase chain reaction (RT-PCR) and the inductively coupled plasma mass spectrometry (ICP-MS) studies. All subjects were clinically healthy, had died suddenly in accidents, were dead on arrival and had full autopsies. Autopsy subjects had a negative toxicology screening 
panel, including drug alkaline and acid/neutral screen, amphetamines, benzodiazepines, cocaine/opiates, alcohol, volatiles and cannabinoids.

Data available for all subjects included age, gender, place of residency, cause of death, and time between death and autopsy. Cause of death was considered for all subjects to rule out the possibility that infection, inflammatory events, drug exposure, brain ischemia and hypoxia might impact the mRNA levels of the inflammatory markers measured in the study.

\section{Autopsy and tissue preparation}

Autopsies were performed $3.9 \pm 1.1 \mathrm{~h}$ after death. The postmortem period was similar for controls and exposed. The skull was opened and the olfactory bulbs and the brain removed. Selected areas from alternating right and left superior frontal gyri (prefrontal lobe) were dissected and kept at $-80^{\circ} \mathrm{C}$ for the inductively coupled plasma mass spectrometry (ICPMS). Frozen tissue for the RT-PCR were taken from the cortex and the white matter in the same regions as the samples for ICP-MS. Sections from the right lung (anterior basal lower right lobe) were also taken for both ICP-MS and RT-PCR.

\section{Inductively coupled plasma mass spectrometry (ICP-MS)}

Frozen tissue was used for ICP-MS analysis using a Perkin-Elmer Sciex ELAN DRCII Inductively coupled plasma mass spectrometer housed in a HEPA filtered metal free laboratory. Each sample was dried, weighed and microwave digested in a closed vessel with nitric acid. The resulting solutions were analyzed directly for their $\mathrm{V}, \mathrm{Ni}, \mathrm{Co}, \mathrm{Pb}, \mathrm{Fe}, \mathrm{Zn}, \mathrm{As}$, $\mathrm{Cr}, \mathrm{Mn}, \mathrm{Se}$ and $\mathrm{Cu}$ content following EPA 6020 modified protocol (USEPA 1994). Calibration standards were matrix matched to sample digests and calibration verification standards were analyzed following every 10 samples. Reagent blanks, spiked samples and certified standard tissues (Dog fish liver and Dog fish muscle reference materials for trace metals National Research Council Canada and 1577 bovine liver US National Bureau for Standards) were carried through the digestion process with the samples and evaluated for quality assurance. Background represented by blank samples was measured at least 10 times, assuring adequate signal above baseline noise. The recovery of added metals in the tissue matrix spikes was monitored and evaluation of these parameters for each digestion batch ensured comparability, precision and accuracy.

\section{Estimation of mRNA abundance by real-time RT-PCR}

Total RNA was extracted from frozen lungs and frontal cortex using Trizol Reagent (Invitrogen Corp, Carlsbad CA) according to the manufacturer instructions. Random-primed first-strand cDNAs were generated as described (Calderón-Garcidueñas et al. 2008b). RNA integrity, concentration, and purity were determined by spectrophotometry using the NanoDrop ND-1000, keeping only samples with the OD A260/A280 and the OD A260/ A230 ratios close to 2.0. Relative abundances of mRNAs encoding COX2, interleukin-1 beta (IL-1 $\beta$ ), 8-oxoguanine DNA glycosylase (OGG1), DNA ligase I (L1G1) and DNA repair protein complementing XP-A cells (XPA) were estimated by quantitative fluorogenic 5' nuclease (TaqMan) assay of the first strand cDNAs as described (Calderón-Garcidueñas et al. 2008b). Primers and fluorophore-labeled TaqMan probes of the target genes were designed using Primer Designer software (Scientific and Educational Software, Durham, NC) based upon sequence information in GenBank.

\section{Statistics}

Statistical analyses were performed using SAS Statistical software 9.2 version. We consider a simple linear regression model. This model contains only one explanatory variable (e.g., age or gene expressions) and one response variable (e.g., metal concentrations). Before the 
analysis, we use Cook's D statistic to identify all the potentially unusual or influential points and then fit simple linear model by removing the influential points. The regression analysis was performed for the combination of each of ten metals and each of gene expressions or the combination of each of ten metals and age. In the first case, the metals were considered as the independent variable whereas in the second case, the metals were considered as the dependent variable. We also applied the Wilcoxon rank sum test with continuity correction to compare the differences in the metal concentrations in controls versus exposed subjects. Significance was assumed at $p<0.05$. Data are expressed as mean values $\pm S D$, except the average age of the subjects that was expressed as standard error (SE).

\section{Results}

\section{Air Quality Data}

MC residents are continuously exposed year-round to air pollutant concentrations above the United States' current National Air Ambient Quality Standards (NAAQS). High concentrations of fine particulate matter $\left(\mathrm{PM}_{2.5}\right)$ are present in $\mathrm{MC}$ air. Figure 1 shows the trend of 24-hr $\mathrm{PM}_{2.5}$ average concentrations from 2004 to 2010 in the Mexico City Metropolitan Area according to data from the official air quality monitoring network. The upper levels typically correspond to the northern areas and the lower concentrations to the southern part of the city. Long term $\mathrm{PM}_{2.5}$ levels and thus chronic exposures have been consistently high regardless of the location within the metropolitan area. $\mathrm{PM}_{2.5}$ concentrations in Mexico City tend to peak during the mid-to-afternoon hours coinciding with children's school and outdoor activities (Villarreal-Calderón et al. 2002; Salcedo et al. 2006).

\section{Study population}

The average age for the study cohorts of 12 controls ( $30.4 \pm 6.5 \mathrm{y}$ SE) and 47 highly exposed $(35.7 \pm 3.1$ y SE) subjects was $33.06 \pm 4.8 \mathrm{SE}$ years $(\mathrm{p}=0.44)$. The cohorts included 14 children ages 2-17 years, $\mathrm{n}: 5$ in the control and n: 9 in the MC group, average age 15.4 $\pm 1.1 \mathrm{SE}$ and $13.2 \pm 1.4 \mathrm{SE}$ respectively $(\mathrm{p}=0.25)$. None of the subjects had occupational exposures to metals (Supplemental Table 1).

\section{Lung and frontal cortex metal concentrations}

Metal concentrations were expressed as $\mu \mathrm{g} / \mathrm{gr}$ of dry tissue. We found no significant differences in lung metal concentrations between control (CTL) and MC subjects (Table 1). Frontal cortex concentrations of $\mathrm{Mn}(\mathrm{p}=0.003), \mathrm{Ni}(\mathrm{p}=0.02)$ and $\mathrm{Cr}(\mathrm{p}=0.02)$ were higher in Mexico City subjects than in CTL (Table 1).

\section{Real-time PCR mRNA analysis of COX2, IL1 $\beta$, OGG1, L1G1 and XPA}

RT-PCR analysis of the target genes in lungs and frontal cortex from 59 subjects indicated that the corresponding mRNA was present in each of the samples analyzed. Table 2 summarizes the results and statistical analysis. COX2 expression in the lung was significantly elevated in the high exposure group vs. CTL, $p=0.01$. No differences among cohorts were seen with IL1 $\beta$. There were no significant correlations between lung metal concentrations and COX2 or IL $1 \beta$ lung expression. COX2 in the frontal cortex was significantly elevated in Mexico City subjects vs. CTL, $p=0.008$. Exposed subjects also had higher IL $1 \beta$ expression in the frontal cortex, $p=0.0002$. COX 2 in olfactory bulb was significantly elevated vs. CTL, $\mathrm{p}=0.005$. Frontal cortex and olfactory bulb showed no significant differences between groups in the DNA repair genes OGG1, L1G1 and XPA (Table 2). 
Table 3 summarizes the regression analysis results between frontal cortex metal concentrations and expression of the selected genes in frontal and olfactory bulb samples for Mexico City residents. Similar analysis for CTL yielded no statistical significant correlations.

In highly exposed subjects, there were four significant negative correlations: Mn and frontal $\operatorname{IL} 1 \beta(\mathrm{p}=0.00001), \mathrm{Cu}$ and XPA frontal $(\mathrm{p}=0.0053), \mathrm{Zn}$ and frontal $\mathrm{IL} 1 \beta(\mathrm{p}=0.01)$ and Se and olfactory bulb COX2 ( $\mathrm{p}=0.04)$. Increased frontal concentrations of Co correlated with decreases of OGG1- that encodes the enzyme responsible for the excision of 8-oxoguaninein olfactory bulb. Both Co and Cu correlated negatively with L1G1- encoding DNA ligase I with functions in DNA replication and the base excision repair (BER) process- in olfactory bulb. While high frontal Ni correlated with high IL1 $\beta$ in olfactory bulb. Higher concentrations of frontal cobalt correlated with lower expression of frontal COX2 $(\mathrm{p}=0.0024)$. Olfactory bulb higher XPA expression correlated with higher frontal $\mathrm{Cr}, \mathrm{Zn}$, and As concentrations and higher hippocampus COX2 expression correlated positively with $\mathrm{Mn}$ and $\mathrm{Cu}$ frontal concentrations $(\mathrm{p}<0.001)$.

\section{Age and frontal cortex metal concentrations}

We did not observe any statistically significant age effects in frontal cortex metal concentrations in the control cohort. Table 4 summarizes the relationship between age and concentrations of different metals in the frontal lobe in Mexico City residents. Frontal concentrations of $\mathrm{Co}, \mathrm{Mn}$ and $\mathrm{Se}$ ( $\mathrm{p}$ values $0.008,0.01$ and 0.007, respectively) increased as Mexico City residents aged.

\section{Discussion}

Three major findings are seen in this work, the first one is that children and adults living in a highly polluted megacity have increased frontal cortex concentrations of road-traffic, combustion and industry-associated metals including $\mathrm{Mn}, \mathrm{Cr}$ and $\mathrm{Ni}$ when compared with residents from lower air pollution cities. The second one, is a finding we have reported before in similar Mexico City cohorts v controls (Calderón-Garcidueñas et al.,2004, 2008b, 2011b): the presence of neuroinflammation in highly exposed young urbanites as established by the significant frontal and olfactory bulb up-regulation of two key inflammatory mediators: interleukin- $1 \beta$ and COX2. The third one is that lung COX2 expression is a good marker of inflammation in exposed individuals,

We also confirmed our previous observations (Calderón-Garcidueñas et al., 2002,2003b, 2004,2010 ) that the olfactory bulb-exposed directly to the outside environment through the olfactory sensory neurons making their first synapse at the glomerular level (Kalinke et al., 2011)- get the direct impact of environmental matters as evidenced by the COX2 upregulation. Of particular interest are the significant correlations between frontal metals and mRNA expression of targeted inflammatory and DNA repair genes and the potential role of metals in the multiple levels of regulation of brain cytokine production, activity and cellular release (Allan et al., 2005).

The presence in the urbanites' brain of metals clearly associated with PM in Mexico City (Querol et al. 2008) and present in a plant biomonitor Ficus benjamina (the total metal leaves concentration reflecting airborne metals)(Guzmán-Morales et al. 2011) confirms one major source of metals (i.e., airborne) capable of accessing the CNS in humans. A key point in the work from researchers measuring atmospheric metal pollution in Mexico City being "metal concentrations strongly depend on the specific urban sub-area" (Guzmán-Morales et al. 2011) a statement that also has a profound impact on children's health and pediatrician 
awareness that place of residency within Mexico City has to be integrated with the risk for CNS detrimental effects.

Particulate matter is indeed an effective vehicle for brain access (Calderón-Garcidueñas et al., 2001b, 2002,2003b, 2004, 2010; Terzano et al., 2010; Nakane 2011; Morgan et al., 2011) and evidence that the nasal-brain connection pathway is important, is the fact that metals such as $\mathrm{Ni}$ and $\mathrm{V}$ are present in a gradient from olfactory mucosa $>$ olfactory bulb $>$ frontal cortex in Mexico City residents (Calderón-Garcidueñas et al., 2003b)

Our interest in DNA repair genes rest in the evidence that their expression is a good indicator of oxidative stress (Powel et al. 2005) and metals have well known oxidative, neurotoxic, neurodevelopmental and neurobehavioral effects (Barth et al. 2002; ColinBarenque et al. 2008; Afeseh-Ngwa et al. 2011; Todorich et al. 2011; Winneke 2011; Yen et al. 2011;Martinez et al. 2011). Repair enzymes recognize and remove DNA adducts, correct the DNA sequence and rejoin strand breaks. DNA damage as a result of oxidative stress is considered the most common insult affecting the genome (Kawanishi et al. 2001).

Frontal chromium and arsenic concentrations correlated positively with the expression of XPA in the olfactory bulb. XPA, a nucleotide-excision repair (NER) system enzyme is capable of recognizing and repairing a large variety of DNA helix-distorting lesions, including DNA intra-strand cross-links (Zhang et al. 2009). The significant correlation between frontal $\mathrm{Cr}$ and $\mathrm{OB}$ XPA is important given that $\mathrm{Cr}$ is the most potent inducer of DNA-protein cross links (DPC) and XPA is a key factor of the human nucleotide excision repair system (Reynolds et al. 2004; O'Brien et al. 2005; Kang et al. 2011).

The positive association between frontal As and olfactory bulb XPA is interesting because the finding reflects the diverse environmental pollution sources impacting the brain. Sources of arsenic in Mexico City include anthropogenic sources associated with PM (Querol et al. 2008), contaminated drinking water (Jiménez et al. 2004) and volcanic sediments (Nordstrom 2002). Groundwater in Mexico City is vulnerable to contaminants from waste dumps and industrial sites and waste water sludge contains arsenic and nickel (Jiménez et al. 2004).

The negative associations between frontal IL1 $\beta$ and the concentrations of $\mathrm{Mn}, \mathrm{Cu}$ and $\mathrm{Zn}$ are intriguing and a recent paper by Matousek et al., could shed some light in the issue (Matousek et al., 2011). The authors argue for a neuroprotective role of IL1 $\beta$ overexpression. In a mouse model of Alzheimer's disease (APP/PS1-IL1 $\beta^{\mathrm{XAT}}$ ) IL1 $\beta$ results in decrease 6E10 (an antibody reactive to the amino acid residue 1-16 of beta amyloid) immunoreactive plaque pathology regardless of age and duration (Matousek et al., 2011). Thus, in our scenario of sustained exposures to significant concentrations of PM, the negative correlation between metals and mRNA IL1 $\beta$ requires comparing mRNA expression to protein abundance. The issue is very relevant because $51 \%$ of children and young adults Mexico City residents with sudden accidental deaths exhibit amyloid- $\beta$ (A $\beta$ ) diffuse plaques compared with 0\% in controls (Calderón-Garcidueñas et al., 2011b).

The brain cytokine interplay is the context of air pollution is poorly understood and their involvement during multiple physiological and pathological processes might change under sustained neurotoxic stimuli (Allan et al 2005; Dinarello 2011). Interleukin-1 beta activity for example, is tightly controlled and endogenous and exogenous stimulants induce the synthesis of the inactive IL-1 $\beta$ precursor or the specific inhibitor IL-1 receptor antagonist (Dinarello 2011). The multiple levels of regulation of IL-1 $\beta$ production, activity and cellular release (Allan et al., 2005) and the impact of metals affecting these processes in the brain and leading to changes in IL-1 expression at the mRNA level and/or the protein level needs to be understood in order to define the extent of the metal neurotoxicity. 
Critical to this air pollution scenario and the targeted olfactory bulb, is the fact that neuroblasts from the subventricular zone (SVZ) migrate along the rostral migratory stream (RMS) into the olfactory bulb, where they differentiate into interneurons (Whitman and Greer 2009). Once reaching the core of the olfactory bulb, immature neurons detach from the RMS and migrate radially toward glomeruli where they differentiate into different subtypes of interneurons (Ming and Song 2011). Metal-related toxic effects could damage these immature neurons and could have a negative impact on adult neurogenesis.

Smell disturbances have been described in workers exposed to $\mathrm{Cr}$ even in the absence of nasal lesions (Kitamura et al., 2003) and the intranasal application of $\mathrm{ZnSO} 4$ to mice produces a brief but total disruption of functional connections from the olfactory epithelium to the main olfactory bulb and a transient anosmia (MacBride 2003). The ultimate effects of DNA damage and inflammation in the olfactory bulb will be reflected in significant apurinic/ apyrimidinic sites, olfactory function deficits and neurodegeneration already seen in Mexico City young residents (Calderón-Garcidueñas et al. 2003b, 2008b, 2010, 2011b).

In the context of PM exposure (Chow et al. 2002; Querol et al. 2008; Guzmán-Morales et al. 2011) a key observation in this relatively young cohort is the frontal increase in $\mathrm{Mn}, \mathrm{Ni}$ and $\mathrm{Cr}$ concentrations compared to controls. The increasing and sustained accumulation of $\mathrm{Mn}$ in frontal cortex tissue is critical and occurs despite homeostatic mechanisms that tightly restrict Mn absorption and regulate Mn excretion to maintain stable tissue levels (Schroeter et al. 2011). Inhalation is the exposure route of most concern for our pediatric populations because inhaled Mn particles that deposit on lung epithelium bypass uptake control in the GI tract and liver and directly enter the systemic circulation (Schroeter et al. 2011). Children in Mexico City spend a considerable amount of time outdoors and their respiratory rate is higher than adults, both factors potentially contributing to an increased nasal and lung deposition (Villarreal-Calderon et al. 2002). Further, these children already have significant nasal pathology with a breakdown of the nasal and olfactory barriers that could facilitate particulate matter to penetrate the brain via the olfactory bulb and the systemic circulation (Calderón-Garcidueñas et al. 2001, 2010).

Manganese is an essential trace element and several studies have shown distinct pathways contributing to Mn influx into the brain and Mn neurotoxicity (Aschner et al. 2007; Frick et al. 2011; Dorman et al. 2008; Erikson et al. 2007, 2008; Rao et al. 2010; Chtourou et al. 2011; Schmitt et al. 2011; Fitsnakis et al. 2011). An active transport at the blood-CSF barrier allows for a unidirectional $\mathrm{Mn}$ transport across the choroid plexus, a pathway of special importance in developing animals (Schmitt et al. 2011). Oxidative stress and a redox state imbalance are critical factors in Mn toxicity (Frick et al. 2011; Dorman et al. 2008; Erikson et al. 2008; Chtourou et al. 2011).

Studies in non-primates have provided invaluable insights into the CNS effects of Mn (Guilarte 2010; Burton and Guilarte 2009; Schneider et al. 2009). Chronic Mn exposures in macaques produce subtle deficits in cognition and motor function and metabolic changes using magnetic resonance imaging of the brain (Burton and Guilarte 2009). Moreover, upregulation of the amyloid beta precursor-like protein 1 gene along with Mn inducible frontal regulation of gene expression are also present (Guilarte 2010). Diffuse amyloid plaques and a synuclein aggregation in the frontal cortex complete the Mn responses observed in juvenile animals (Guilarte 2010). A spectrum of cognitive deficits have also been described in children exposed to $\mathrm{Mn}$ in drinking water, living in the proximity of a ferro-manganese alloy plant and in occupationally exposed workers (Mergler et al. 1994; Lucchini et al. 1995; Wasserman et al. 2006; Bouchard et al. 2007, 2008; Menezes-Filho et al. 2011). Our observation of a positive association between hippocampal COX2 expression and frontal $\mathrm{Mn}$ is interesting in view of the memory deficits seen in our pediatric populations (Calderón- 
Garcidueñas et al. 2008c, 2011c) and the cognition deficits involving memory in occupational settings, and in children living in close proximity to ferro-manganese alloy plants (Mergler et al. 1994; Lucchini et al. 1995; Wasserman et al. 2006; Bouchard et al. 2007, 2008; Menezes-Filho et al. 2011). Although we have no evidence in our children's clinical cohorts of any MRI or MRS changes affecting those areas targeted by Mn in nonhuman primates i.e., striatum and thalamus (Burton and Guilarte 2009), studies are underway to define the presence of Mn exposure biomarkers in our populations (MarreilhaDosSantos et al. 2011; Zheng et al. 2011; Kim et al. 2011).

Residents in Mexico City also increased their frontal lobe concentrations of cobalt and selenium with age. Cobalt, a component of Vitamin $B_{12}$ (Banerjee and Ragsdale 2003) is an essential nutrient, however increases in Co ions can directly induce DNA damage, interfere with DNA repair, and lead to DNA-protein cross linking and sister chromatid exchange (Leonard et al. 1998; Hengstler et al. 2003). Selenium, on the other hand, participates in antioxidant responses as a component of glutathione peroxidases and Se transporting proteins. Se prevents free-radical formation by enhancing antioxidant activity and their role in neurodegenerative diseases such as Alzheimer has been extensively studied (Loef et al., 2011). Two recent reports point to the protective effects of Selenium, with van Eersel, et al. demonstrating that sodium selenate reduced tau phosphorylation both in vitro and in vivo in tau transgenic mouse strains with neurofibrillary tangle pathology (van Eersel et al. 2010).

Se treatment improved contextual memory and motor performance, and prevented neurodegeneration in tau transgenic mice carrying a K369I mutation in neurons. van Eersel et al concluded that sodium selenate stabilizes the serine/threonine-specific protein phosphatase 2A (PP2A)-tau complex and mitigates tau pathology in several AD models (van Eersel et al. 2010). In the work of Ralston and Raymond, dietary Se protected against methylmercury toxicity (Ralston and Raymond 2010). Thus, the brain increases of Se with age is an intriguing finding that could only be defined clearly if measurement of key selenoproteins are done in parallel with total Se concentrations in several brain anatomical regions (Loef et al., 2011).

The issue of metals and brain pathology has not been extensively researched in pediatric populations exposed to urban pollution, but it is clear that for redox-active transition metals, their ability to generate reactive oxygen species (Ali et al. 1995; Bleackley and MacGillivray, 2011) ought to be a critical factor for injury to the developing brain (Yoon et al. 2011).

The significant down regulation of the prion cellular protein $\left(\operatorname{PrP}^{\mathrm{C}}\right)$ in the frontal cortex of Mexico City children and young adults versus controls (Calderón-Garcidueñas et al. 2011b) could be added to factors altering metal homeostasis in air pollution exposed young populations The prion protein interferes with divalent metal Mn uptake and protects against Mn-induced oxidative stress and apoptotic cell death (Choi et al. 2007). Divalent metal manganese can alter the stability of prion proteins and Choi et al., work suggest that manganese-induced stabilization of the prion protein may play a role in prion protein misfolding and prion disease (Choi et al. 2010).

In summary, children and adults with lifelong exposures to a polluted urban environment accumulate road-traffic, combustion and industrial-associated metals in their frontal lobes and there is significant neuroinflammation as supported by the up-regulation of frontal interleukin- $1 \beta$ and COX2. This work supports our previous observations that the olfactory bulb is a target of air pollution and participates in the neuroinflammatory response. The significant correlation between well known PM-associated toxic metals (i.e., Mn) and gene expression of inflammatory genes and DNA repair genes points to the critical issue of the impact of metal neurotoxicity in exposed residents, particularly children and our concern for 
long-term neural effects. Pohl et al. made a critical point pertinent to our studies, especially regarding the neurotoxicity impact on our pediatric populations "interactions or "joint toxic actions" may occur in populations exposed to mixtures of metals or to mixtures of metals with other chemicals" (Pohl et al. 2011).

Metal neurotoxicity might put young urban populations at considerable risk for brain damage and since metal concentrations vary significantly in Mexico City urban sub-areas, place of residency has to be integrated with the risk for CNS detrimental effects particularly in children.

The oxidative damage to frontal lobes in this young urbanite cohort poses a significant cause for concern in terms of developmental and cognitive effects (Barth et al. 2002; Burton and Guilarte 2009; Guilarte 2010; Martinez et al. 2011; Todorich et al. 2011; Winneke 2011).

\section{Supplementary Material}

Refer to Web version on PubMed Central for supplementary material.

\section{Acknowledgments}

This work supported in part by 1KO1 NS046410-01A1, 1R21ES013293-01, 2RO1 ES010975 and ITHS UL1RR025014

\section{REFERENCES}

Afeseh-Ngwa H, Kanthasamy A, Anantharam V, Song C, Witte T, Houk R, et al. Vanadium induces dopaminergic neurotoxicity via protein kinase $\mathrm{C}$ delta dependent oxidative signaling mechanisms: relevance to etiopathogenesis of Parkinson's disease. Toxicol Appl Pharmacol. 2009; 240:273-285. [PubMed: 19646462]

Alfaro-Moreno E, Martínez L, García-Cuellar C, Bonner JC, Murray CJ, Rosas I, et al. Biological effects induced in vitro by $\mathrm{PM}_{10}$ from three different zones of Mexico City. Environ Health Perspect. 2002; 110:715-720. [PubMed: 12117649]

Alfaro-Moreno E, Ponce de León S, Osornio-Vargas AR, García-Cuellar C, Rosas I. Potential toxic effects associated to metals and endotoxin present in $\mathrm{PM}_{10}$ : an ancillary study using multivariate analysis. Inhal Toxicol. 2007; 19:49-53. [PubMed: 17886050]

Ali SF, Duhart HM, Newport GD, Lipe GW, Slikker W Jr. Manganese-induced reactive oxygen species: comparison between $M n+2$ and $M n+3$. Neurodegeneration. 1995; 4:329-334. [PubMed: 8581566]

Ali J, Ali M, Baboota S, Sahani JK, Ramassammy C, Bhavna DL. Potential of nanoparticulate drug delivery systems by intranasal administration. Curr Pharm Des. 2010; 16:1644-1653. [PubMed: 20210751]

Allan SM, Tyrrell PJ, Rothwell NJ. Interleukin-1 and neuronal injury. Nat Rev Immunol. 2005; 5:629640. [PubMed: 16034365]

Aschner M, Guilarte TR, Schneider JS, Zheng W. Manganese: recent advances in understanding its transport and neurotoxicity. Toxicol Applied Pharmacol. 2007; 221:131-147.

Ayres JG, Borm P, Cassee FR, Castranova V, Donaldson K, Ghio A, et al. Evaluating the toxicity of airborne particulate matter and nanoparticles by measuring oxidative stress potential-a workshop report and consensus statement. Inhal Toxicol. 2008; 20:75-99. [PubMed: 18236225]

Banerjee R, Ragsdale SW. The many faces of vitamin B12: catalysis by cobalamin-dependent enzymes. Annu Rev Biochem. 2003; 72:209-247. [PubMed: 14527323]

Barth A, Schaffer AW, Konnaris C, Blauensteiner R, Winker R, Osterode W. Neurobehavioral effects of vanadium. J Toxicol Environ Health A. 2002; 65:677-683. [PubMed: 11996408]

Bleackley MR, Macgillivray RT. Transition metal homeostasis: from yeast to human disease. Biometals. 2011; 24:785-809. [PubMed: 21479832] 
Block ML, Calderón-Garcidueñas L. Air pollution: mechanisms of neuroinflammation and CNS disease. Trends in Neurosci. 2009; 32:506-516.

Bolognin S, Messori L, Zatta P. Metal ion physiopathology in neurodegenerative disorders. Neuromol Med. 2009; 11:223-238.

Bravo-Alvarez HR, Torres-Jardón R. Air pollution levels and trends in the México City metropolitan area. In: Urban Air Pollution and Forest: Resources at Risk in the Mexico City Air Basin. Ecological Studies. 2002; 156:121-159.

Bouchard M, Laforest F, Vandelac L, Bellinger D, Mergler D. Hair manganese and hyperactive behaviors: pilot study of school-age children exposed through tap water. Environmental Health Perspectives. 2007; 115:122-127. [PubMed: 17366831]

Bouchard M, Mergler D, Baldwin ME, Panisset M. Manganese cumulative exposure and symptoms: a follow-up study of alloy workers. Neurotoxicology. 2008; 29:577-583. [PubMed: 18562007]

Burton NC, Guilarte TR. Manganese neurotoxicity: lessons learned from longitudinal studies in nonhuman primates. Environmental Health Perspectives. 2009; 117:325-332. [PubMed: 19337503]

Calderón-Garcidueñas L, Gambling TM, Acuña H, García R, Osnaya N, Monroy S, et al. Canines as sentinel species for assessing chronic exposures to air pollutants: Respiratory and Cardiac Pathology. Toxicol Sci. 2001a; 61:342-367. [PubMed: 11353143]

Calderón-Garcidueñas L, Valencia-Salazar G, Rodríguez-Alcaraz A, Gambling TM, García R, Osnaya $\mathrm{N}$, et al. Ultrastructural nasal pathology in children chronically and sequentially exposed to air pollutants. Am J Respir Cell Mol Biol. 2001b; 24:132-138. [PubMed: 11159046]

Calderón-Garcidueñas L, Azzarelli B, Acuña H, Gambling TM, Monroy S, Tizapantzi MR, Carson JL, Villarreal-Calderon A, Rewcastle B. Air pollution and brain damage. Toxicol Pathol. 2002; 30:373-389. [PubMed: 12051555]

Calderón-Garcidueñas L, Mora-Tiscareño A, Fordham LA, Valencia-Salazar G, Chung CJ, RodríguezAlcaraz A, et al. Respiratory damage in children exposed to urban pollution. Pediatric Pulmonol. 2003a; 36:148-161.

Calderón-Garcidueñas L, Maronpot RR, Torres-Jardon R, Henríquez-Roldán C, Schoonhoven R, Acuña-Ayala $\mathrm{H}$, et al. DNA damage in nasal and brain tissues of canines exposed to air pollutants is associated with evidence of chronic brain inflammation and neurodegeneration. Toxicol Pathol. 2003b; 31:524-538. [PubMed: 14692621]

Calderón-Garcidueñas L, Reed W, Maronpot RR, Henriquez-Roldan C, Delgado-Chavez R, CalderónGarcidueñas A, et al. Brain inflammation and Alzheimer's-like pathology in individuals exposed to severe air pollution. Toxicol Pathol. 2004; 32:650-658. [PubMed: 15513908]

Calderón-Garcidueñas L, Vincent R, Mora-Tiscareño A, Franco-Lira M, Henríquez-Roldán C, Garrido-Garcia L, et al. Elevated plasma Endothelin-1 and Pulmonary arterial pressure in children exposed to air pollution. Environ Health Perspect. 2007; 115:1248-1253. [PubMed: 17687455]

Calderón-Garcidueñas L, Villarreal-Calderon R, Valencia-Salazar G, Henríquez-Roldán C, GutiérrezCastrellón P, Torres-Jardon R, et al. Systemic inflammation, endothelial dysfunction, and activation in clinically healthy children exposed to air pollutants. Inhal Toxicol. 2008a; 20:499_ 506. [PubMed: 18368620]

Calderón-Garcidueñas L, Solt A, Franco-Lira M, Henríquez-Roldán C, Torres-Jardón R, Nuse B, et al. Long-term air pollution exposure is associated with neuroinflammation, an altered innate immune response, disruption of the blood-brain-barrier, ultrafine particle deposition, and accumulation of amyloid beta 42 and alpha synuclein in children and young adults. Toxicol Pathol. 2008b; 36:289310. [PubMed: 18349428]

Calderón-Garcidueñas L, Mora-Tiscareño A, Gómez-Garza G, Broadway J, Chapman S, ValenciaSalazar G, et al. Air pollution, cognitive deficits and brain abnormalities: A pilot study with children and dogs. Brain and Cognition. 2008c; 68:117-127. [PubMed: 18550243]

Calderón-Garcidueñas L, Macias-Parra M, Hoffman HJ, Valencia-Salazar G, Henriquez-Roldan C, Osnaya N, et al. Immunotoxicity and Environment: Immunodysregulation and Systemic Inflammation in Children. Toxicol Pathol. 2009; 37:161-169. [PubMed: 19171930] 
Calderón-Garcidueñas L, Franco-Lira M, Henriquez-Roldan C, Osnaya N, Gonzalez-Maciel A, Reynoso-Robles R, et al. Urban air pollution: Influences on olfactory function and pathology in exposed children and young adults. Exp Toxicol Path. 2010; 62:91-102. [PubMed: 19297138]

Calderón-Garcidueñas L, D'Angiulli A, Kulesza RJ, Torres-Jardón R, Osnaya N, Romero L, et al. Air pollution is associated with brainstem auditory nuclei pathology and delayed brainstem auditory evoked potentials. Int J Dev Neurosci. 2011a; 29:365-375. [PubMed: 21458557]

Calderón-Garcidueñas L, Kavanaugh M, Block ML, D'Angiulli A, Delgado-Chávez R, Torres-Jardón $\mathrm{R}$, et al. Neuroinflammation, hyperphosphorilated tau, diffuse amyloid plaques and downregulation of the cellular prion protein in air pollution exposed children and young adults. $\mathrm{J}$ Alzheimer Disease. Sep 28.2011b PMID 21955814.

Calderón-Garcidueñas L, Engle R, Mora-Tiscareño A, Styner M, Gómez-Garza G, Zhu H, et al. Exposure to severe urban air pollution influences cognitive outcomes, brain volume and systemic inflammation in clinically healthy children. Brain \& Cognition. 2011c; 77:345-55. [PubMed: 22032805]

Chen LC, Lippman M. Effects of metals within ambient air particulate matter (PM) on human health. Inhal Toxicol. 2009; 21:1-31. [PubMed: 18803063]

Choi CJ, Anantharam V, Saetveit NJ, Houk RS, Kanthasamy A, Kanthasamy AG. Normal cellular prion protein protects against manganese-induced oxidative stress and apoptotic cell death. Toxicol Sci. 2007; 98:495-509. [PubMed: 17483122]

Choi CJ, Anantharam V, Martin DP, Nicholson EM, Richt JA, Kanthasamy A, Kanthasamy AG. Manganese upregulates cellular prion protein and contributes to altered stabilization and proteolysis: relevance to role of metals in pathogenesis of prion disease. Toxicol Sci. 2010; 115:535-546. [PubMed: 20176619]

Chow JC, Watson JG, Edgerton SA, Vega E. Chemical composition of $\mathrm{PM}_{2.5}$ and $\mathrm{PM}_{10}$ in Mexico City during winter 1997. Sci Total Environ. 2002; 287:177-201. [PubMed: 11993962]

Chtourou Y, Trabelsi K, Fetoui H, Mkannez G, Kallei H, Zeghal N. Manganese induces oxidative stress, redox state imbalance and disrupts membrane bound ATPases on murine neuroblastoma cells in vitro; protective role of Silymarin. Neurochem Res. 2011; 36:1546-57. [PubMed: 21533646]

Colin-Barenque L, Martinez-Hernandez MG, Baiza-Gutman LA, Avila-Costa MR, Ordoñez-Librado JL, Bizarro-Nevares P, et al. Matrix metalloproteinases 2 and 9 in central nervous system and their modification after vanadium inhalation. J Appl Toxicol. 2008; 28:718-723. [PubMed: 18059072]

Dinarello CA. A clinical perspective of IL-1 $\beta$ as the gatekeeper of inflammation. Eur J Immunol. 2011; 41:1203-1217. [PubMed: 21523780]

Dorman DC, Struve MF, Marshall MW, Parkinson CU, James RA, Wong BA. Tissue manganese concentrations in young male rhesus monkeys following subchronic manganese sulfate inhalation. Toxicol Sci. 2006; 92:201-210. [PubMed: 16624849]

Dorman DC, Struve MF, Norris A, Higgins AJ. Metabolomic analysis of body fluids after subchronic manganese inhalation in rhesus monkeys. Toxicol Sci. 2008; 106:46-54. [PubMed: 18684773]

Erikson KM, Thompson K, Aschner J, Aschner M. Manganese neurotoxicity: a focus on the neonate. Pharmacol Ther. 2007; 113:369-377. [PubMed: 17084903]

Erikson KM, Dorman DC, Lash LH, Aschner M. Duration of airborne-manganese exposure in rhesus monkeys is associated with brain regional changes in biomarkers of toxicity. Neurotoxicol. 2008; 29:377-385.

Fitsnakis VA, Zhang N, Avison MJ, Erikson KM, Gore JC, Aschner M. Changes in dietary iron exacerbate regional brain manganese accumulation as determined by magnetic resonance imaging. Toxicol Sci. 2011; 120:146-153. [PubMed: 21177776]

Frick R, Müller-Edenborn B, Schlicker A, Rothen-Rutishauser B, Raemy DO, Gunther D, et al. Comparison of manganese oxide nanoparticles and manganese sulfate with regard to oxidative stress, uptake and apoptosis in alveolar epithelial cells. Toxicol Letter. 2011; 205:163-172.

Guilarte TR. APLP1, Alzheimer's-like pathology and neurodegeneration in the frontal cortex of manganese-exposed non-human primates. Neurotoxicol. 2010; 31:572-574.

Happo MS, Hirvonen MR, Halinen AI, Jalava PI, Pennanen AS, Sillanpaa M, et al. Chemical compositions responsible for inflammation and tissue damage in the mouse lung by coarse and 
fine particulate samples from contrasting air pollution in Europe. Inhal Toxicol. 2008; 20:12151231. [PubMed: 18855153]

Hengstler JG, Bolm-Audorff U, Faldum A, Janssen K, Reifenrath M, Gotte W, et al. Occupational exposure to heavy metals: DNA damage induction and DNA repair inhibition prove co-exposures to cadmium, cobalt and lead as more dangerous than hitherto expected. Carcinogenesis. 2003; 24:63-73. [PubMed: 12538350]

Jiménez B, Mendez JM, Barrios JA, Salgado G, Sheinbaum C. Characterization and evaluation of potential reuse options for wastewater sludge and combined sewer system sediments in Mexico. Water Sci Technol. 2004; 49:171-178. [PubMed: 15259952]

Kalinke U, Bechmann I, Detje CN. Host strategies against virus entry via the olfactory system. Virulence. 2011; 2:367-370. [PubMed: 21758005]

Kang TH, Reardon JT, Sancar A. Regulation of nucleotide excision repair activity by transcriptional and post-transcriptional control of the XPA protein. Nucleic Acids Res. 2011; 39:3176-3187. [PubMed: 21193487]

Kawanishi S, Hiraku Y, Oikawa S. Mechanism of guanine-specific DNA damage by oxidative stress and its role in carcinogenesis and ageing. Mut Res. 2001; 488:65-76. [PubMed: 11223405]

Kim Y, Jeong KS, Song HJ, Lee JJ, Seo JH, Kim GC, et al. Altered white matter microstructural integrity revealed by voxel-wise analysis of diffusion tensor imaging in welders with manganese exposure. Neurotox. 2011; 32:100-109.

Kitamura F, Yokoyama K, Araki S, Nishikitani M, Choi JW, Yum YT, et al. Increase of olfactory threshold in plating factory workers exposed to chromium in Korea. Ind Health. 2003; 41:279285. [PubMed: 12916760]

Kodavanti UP, Schladweiler MC, Gilmour PS, Wallenborn JG, Mandavilli BS, Ledbetter AD, et al. The role of particulate matter-associated zinc in cardiac injury in rats. Environ Health Perspect1. 2008; 16:13-20.

Leonard S, Gannett PM, Rojanasakul Y, Schwegler-Berry D, Castranova V, Vallyathan V, et al. Cobalt-mediated generation of reactive oxygen species and its possible mechanism. J Inorg Biochem. 1998; 70:239-244. [PubMed: 9720310]

Leavens TL, Rao D, Andersen ME, Dorman DC. Evaluating transport of manganese from olfactory mucosa to stratium by pharmacokinetic modeling. Tox Sci. 2007; 97:265-278.

Loef M, Schrauzer GN, Walach H. Selenium and Alzheimer's disease: A systematic review. J Alzheimer's Disease. 2011; 26:81-104. [PubMed: 21593562]

Maier KL, Alessandrini F, Beck-Speir I, Hofer TPJ, Diabate S, Bitterle E, et al. Health effects of ambient particulate matter-biological mechanisms and inflammatory responses to in vitro and in vivo particle exposures. Inh Toxicol. 2008; 20:319-37.

Martinez L, Jimenez V, Garcia-Sepulveda C, Ceballos F, Delgado JM, Niño-Moreno P, et al. Impact of early developmental arsenic exposure on promoter $\mathrm{CpG}$-island methylation of genes involved in neuronal plasticity. Neurochem Int. 2011; 58:574-581. [PubMed: 21300125]

Matousek SB, Ghosh S, Shaftel SS, Kyrkanides S, Olschowka JA, O'Banion MK. Chronic IL-1 $\beta$ mediated neuroinflammation mitigates amyloid pathology in a mouse model of Alzheimer's disease without inducing overt neurodegeneration. J Neuroimmune Pharmacol. Dec 16.2011

Marreilha-DosSantos AP, Lopes-Santos M, Batoréu MC, Aschner M. Prolactin is a peripheral marker of manganese neurotoxicity. Brain Res. 2011; 1382:282-290. [PubMed: 21262206]

Menezes-Filho JA, Novaes C de O, Moreira JC, Sarcinelli PN, Mergler D. Elevated manganese and cognitive performance in school-aged children and their mothers. Environ Res. 2011; 111:156163. [PubMed: 20943219]

Mergler D, Huel G, Bowler R, Iregren A, Belanger S, Bladwin M, et al. Nervous system dysfunction among workers with long-term exposure to manganese. Environ Res. 1994; 64:151-180. [PubMed: 8306949]

Ming GL, Song H. Adult neurogenesis in the mammalian brain: significant answers and significant questions. Neuron. 2011; 70:687-702. [PubMed: 21609825]

Moffet RC, Desyaterik Y, Hopkins RJ, Tivanski AV, Gilles MK, Wang Y, et al. Characterization of aerosols containing $\mathrm{Zn}, \mathrm{Pb}$, and $\mathrm{Cl}$ from an industrial region of Mexico City. Environ Sci Technol. 2008; 42:7091-7097. [PubMed: 18939531] 
Molina LT, Molina MJ. Improving air quality in megacities: Mexico City case study. Ann NY Acad Sci. 2004; 1023:142-158. [PubMed: 15253903]

Molina LT, Kolb CE, de Foy B, Lamb BK, Brune WH, Jimenez JL, et al. Improving air quality in North America's most populous city - overview of the MCMA-2003 campaign. Atmos Chem Phys. 2007; 7:2447-2473.

Moreno T, Querol X, Pey J, Minguillon MC, Perez N, Alastuey A, et al. Spatial and temporal variations in inhalable $\mathrm{Cu} \mathrm{Zn} \mathrm{Pb}$ aerosols within the Mexico City pollution plume. J Environ Monit. 2008; 10:370-378. [PubMed: 18392280]

Morgan TE, Davis DA, Iwata N, Tanner JA, Snyder D, Ning Z, Kam W, Hsu YT, Winkler JW, Chen JC, Petasis NA, Baudry M, Sioutas C, Finch CE. Glutaminergic neurons in rodent models respond to nanoscale particulate urban air pollutants in vivo and in vitro. Environ Health Perspect. 2011; 119:1003-1009. [PubMed: 21724521]

Nakane H. Translocation of particles deposited in the respiratory system: a systematic review and statistical analysis. Environ Health Prev Med. Nov 20.2011

Nong A, Teeguarden JG, Clewell HJ, Dorman DC, Andersen ME. Pharmacokinetic modeling of manganese in the rat IV: assessing factors that contribute to brain accumulation during inhalation exposure. J Toxicol Environ Health. 2008; 71:413-426.

Nordstrom DK. Worldwide occurrences of arsenic in ground water. Science. 2002; 296:2143-2144. [PubMed: 12077387]

O'Brien TJ, Brooks BR, Patierno SR. Nucleotide excision repair functions in the removal of chromium-induced DNA damage in mammalian cells. Mol Cell Biochem. 2005; 279:85-95. [PubMed: 16283517]

Pohl HR, Roney N, Abadin HG. Metal ions affecting the neurological system. Met Ions life Sci. 2011; 8:247-262. [PubMed: 21473383]

Powell CL, Swenberg JA, Rusyn I. Expression of base excision DNA repair genes as a biomarker of oxidative DNA damage. Cancer Lett. 2005; 229:1-11. [PubMed: 16157213]

Querol X, Pey J, Minguillón MC, Pérez N, Alastuey A, Bernabé RM, et al. PM speciation and sources in Mexico during the MILAGRO-2006 Campaign. Atmos Chem Phys. 2008; 8:111-128.

Ralston NV, Raymond LJ. Dietary selenium's protective effects against methylmercury toxicity. Toxicology. 2010; 278:112-123. [PubMed: 20561558]

Rao KV, Jayakumar AR, Reddy PV, Tong X, Curtis KM, Norenberg MD. Aquaporin-4 in manganesetreated cultured astrocytes. Glia. 2010; 58:1490-1499. [PubMed: 20648640]

Rauch S, Peucker-Ehrenbrink B, Molina LT, Molina MJ, Ramos R, Hemond HF. Platinum group elements in airborne particles in Mexico City. Environ Sci Technol. 2006; 40:7554-7560. [PubMed: 17256494]

Reynolds M, Peterson E, Quievryn G, Zhitkovich A. Human nucleotide excision repair efficiently removes Chromium-DNA phosphate adducts and protects cells against chromate toxicity. J Biol Chem. 2004; 29:30419-30424. [PubMed: 15087443]

Rosas-Pérez I, Serrano J, Alfaro-Moreno E, Baumgardner D, Garcia-Cuellar C, Miranda C, et al. Relations between PM10 composition and cell toxicity: A multivariate and graphical Approach. Chemosphere. 2007; 67:1218-1228. [PubMed: 17188738]

Salcedo D, Onasch TB, Dzepina K, Canagaratna MR, Zhang Q, Huffman JA, et al. Characterization of ambient aerosols in Mexico City during the MCMA-2003 campaign with Aerosol Mass Spectrometry: results from the CENICA Supersite. Atmos. Chem. Phys. 2006; 6:925-946.

Schroeter JD, Nong A, Yoon M, Taylor MD, Dorman DC, Andersen ME, et al. Analysis of manganese tracer kinetics and target tissue dosimetry in monkeys and humans with multi-route physiologically based pharmacokinetic models. Toxicol Sci. 2011; 120:481-498. [PubMed: 21205636]

Schmitt C, Strazielle N, Richaud P, Bouron A, Ghersi-Egea JF. Active transport at the blood-CSF barrier contributes to manganese influx into the brain. J Neurochem. 2011; 117:747-756. [PubMed: 21395586]

Sunderman FW Jr. Nasal toxicity, carcinogenicity, and olfactory uptake of metals. Ann Clin Lab Sci. 2001; 31:3-24. [PubMed: 11314863] 
Tang J, Xiong L, Wang S, Wang J, Liu L, Li J, et al. Distribution, translocation and accumulation of silver nanoparticles in rats. J Nanosci Nanotechnol. 2009; 9:4924-4932. [PubMed: 19928170]

Taishi P, Churchill L, De A, Obal F Jr, Krueger JM. Cytokine mRNA induction by interleukin-1 beta or tumor necrosis factor alpha in vitro and in vivo. Brain Res. 2008; 1226:89-98. [PubMed: 18620339]

Terzano C, Di Stefano F, Conti V, Graziani E, Petroianni A. Air pollution ultrafine particles: toxicity beyond the lung. Eur Rev Med Pharmacol Sci. 2010; 14:809-821. [PubMed: 21222367]

Todorich B, Olopade JO, Surguladze N, Zhang X, Neely E, Connor JR. The mechanism of vanadiummediated developmental hypomyelination is related to destruction of oligodendrocyte progenitors through a relationship with ferritin and iron. Neurotox Res. 2011; 19:361-373. [PubMed: 20237879]

US EPA SW-846. Test methods for evaluating solid waste. Physical/Chemical methods, method 6020, revision September 1994.

van Eersel J, Ke YD, Liu X, Delerue F, Kril JJ, Götz J, et al. Sodium selenate mitigates tau pathology, neurodegeneration and functional deficits in Alzheimer's disease models. Proc Natl Acad Sci USA. 2010; 107:13888-13893. [PubMed: 20643941]

Villarreal-Calderón A, Acuña H, Villarreal-Calderón J, Garduño M, Henríquez-Roldán C, CalderónGarcidueñas L, et al. Assessment of physical education time and after-school outdoor time in elementary and middle school students in south Mexico City: the dilemma between physical fitness and the adverse health effects of outdoor pollutant exposure. Arch Environ Health. 2002; 57:450-460. [PubMed: 12641189]

Villarreal-Calderon R, Torres-Jardon R, Osnaya N, Perez-Guillé B, Maronpot RR, Reed W, et al. Urban Air Pollution Targets the Dorsal Vagal Complex and Dark Chocolate Offers Neuroprotection. Int J Toxicol. 2010; 29:604-615. [PubMed: 21030725]

Wasserman GA, Liu X, Parvez F, Ahsan H, Levy D, Factor-Litvak P, et al. Water manganese exposure and children's intellectual function in Araihazar, Bangladesh. Environ Health Perspect. 2006; 114:124-129. [PubMed: 16393669]

Winneke G. Developmental aspects of environmental neurotoxicology: Lessons from lead and polychlorinated biphenyls. J Neurol Sci. 2011; 308:9-15. [PubMed: 21679971]

Whitman MC, Greer CA. Adult neurogenesis and the olfactory system. Progress Neurobiol. 2009; 89:162-175.

Yen CC, Ho TJ, Chang CF, Su CC, Chen YW, Jinn TR, et al. Inorganic arsenic causes cell apoptosis in mouse cerebrum through an oxidative stress-regulated signaling pathway. Arch Toxicol. 2011; 85:565-575. [PubMed: 21533816]

Yoon M, Schroeter JD, Nong A, Taylor MD, Dorman DC, Andersen ME, et al. Physiologically based pharmacokinetic modeling of fetal and neonatal manganese exposure in humans: Describing Manganese homeostasis during development. Toxicol Sci. 2011; 122:297-316. [PubMed: 21622944]

Zatta P, Drago D, Zambenedetti P, Bolognin S, Nogara E, Peruffo A, et al. Accumulation of copper and other metal ions and metallothionein I/II expression in the bovine brain as a function of aging. J Chem Neuroanat. 2008; 36:1-5. [PubMed: 18485665]

Zhang Y, Rohde LH, Wu H. Involvement of nucleotide excision and mismatch repair mechanisms in double strand break repair. Curr Genomics. 2009; 10:250-258. [PubMed: 19949546]

Zheng W, Fu SX, Dydak U, Cowan DM. Biomarkers of manganese intoxication. Neurotoxicol. 2011; $32: 1-8$.

Exp Toxicol Pathol. Author manuscript; available in PMC 2014 July 01. 


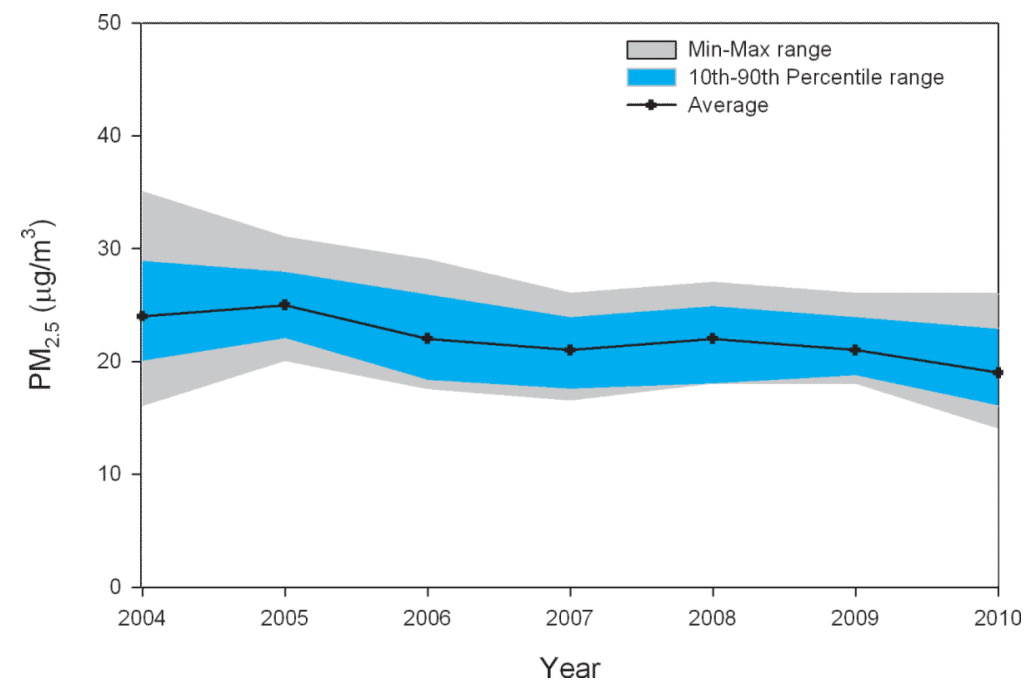

Figure 1. Twenty-four hour particulate matter $\left(2.5 \mu \mathrm{m}\right.$ in diameter or smaller) $\mathbf{P M}_{2.5}$ average concentrations trend from 2004 to 2010 in the Mexico City Metropolitan Area

Metropolitan Mexico City residents are exposed to concentrations of $\mathrm{PM}_{2.5}$ above the current standards regardless of location of their residency. Most metals in Mexico City are contained in the $\mathrm{PM}_{2.5}$ fraction. 


\section{Table 1}

Metal concentrations (Mean \pm SD) in control and exposed lungs and frontal lobe samples expressed as $\mu \mathrm{g} / \mathrm{g}$ dry tissue

\begin{tabular}{lcccc}
\hline Metals & CTL Lungs & MC Lungs & CTL Frontal & MC Frontal \\
$\mathrm{V}$ & $180 \pm 26$ & $214 \pm 32$ & $80 \pm 32$ & $118 \pm 14$ \\
$\mathrm{Ni}$ & $145 \pm 30$ & $275 \pm 42$ & $42 \pm 11$ & $124 \pm 29 *$ \\
$\mathrm{Mn}$ & $609 \pm 87$ & $845 \pm 86$ & $689 \pm 119$ & $1026 \pm 47^{* *}$ \\
$\mathrm{~Pb}$ & $456 \pm 169$ & $374 \pm 126$ & $28 \pm 11$ & $67.8 \pm 20$ \\
$\mathrm{Cr}$ & $1368 \pm 179$ & $2524 \pm 581$ & $527 \pm 85$ & $910 \pm 63$ \\
$\mathrm{As}$ & $94 \pm 18$ & $79 \pm 9$ & $78 \pm 20$ & $127 \pm 13$ \\
$\mathrm{Zn}$ & $69429 \pm 7273$ & $61781 \pm 2983$ & $41741 \pm 5869$ & $46878 \pm 2202$ \\
$\mathrm{Se}$ & $2227 \pm 402$ & $2376 \pm 149$ & $641 \pm 312$ & $1111 \pm 148$ \\
$\mathrm{Cu}$ & $4922 \pm 280$ & $5207 \pm 232$ & $15745 \pm 2209$ & $17058 \pm 746$ \\
$\mathrm{Co}$ & $206 \pm 123$ & $158 \pm 35$ & $15 \pm 2$ & $17 \pm 2$ \\
$\mathrm{Fe}$ & $1.073 \mathrm{e}+006 \pm 100200$ & $1.050 \mathrm{e}+006 \pm 851239$ & $120764 \pm 82519$ & $175001 \pm 75976$ \\
\hline$*$ & & & & \\
$\mathrm{p}=0.02$ & & & & \\
$* *$ & & & & \\
$\mathrm{p}=0.003$ & & & & \\
\hline
\end{tabular}




\section{Table 2}

RT-PCR results from Control v MC lung and CNS selected tissues

\begin{tabular}{llll}
\hline Anatomical region and target gene & Controls & Mexico City & p value \\
LUNG COX2 & $15.9 \pm 6.7 \times 10^{6}$ & $42.3 \pm 7.4 \times 10^{6}$ & $\mathrm{p}=0.01$ \\
FRONTAL COX2 & $2.6 \pm 0.4 \times 10^{5}$ & $5.0 \pm 0.7 \times 10^{5}$ & $\mathrm{p}=0.008$ \\
FRONTAL IL1 $\beta$ & $0.6 \pm 0.2 \times 10^{4}$ & $6.2 \pm 1.3 \times 10^{4}$ & $\mathrm{p}=0.0002$ \\
OB COX2 & $6.3 \pm 1.4 \times 10^{4}$ & $7.9 \pm 8.7 \times 10^{5}$ & $\mathrm{p}=0.005$ \\
OB IL1 $\beta$ & $2.5 \pm 0.95 \times 10^{4}$ & $4.08 \pm 12.3 \times 10^{5}$ & $\mathrm{p}=0.08$ \\
FRONTAL L1G1 & $0.18 \pm 0.16$ & $2.4 \pm 7.7$ & $\mathrm{p}=0.06$ \\
FRONTAL OGG1 & $1.91 \pm 1.22 \times 10^{-3}$ & $1.297 \pm 4.459$ & $\mathrm{p}=0.06$ \\
FRONTAL XPA & $1.872 \pm 1.365 \times 10^{-3}$ & $3.611 \pm 9.847 \times 10^{-2}$ & $\mathrm{p}=0.22$ \\
OB L1G1 & $3.285 \pm 1.316 \times 10^{-2}$ & $0.5557 \pm 1.357$ & $\mathrm{p}=0.34$ \\
OB OGG1 & $5.547 \pm 1.986 \times 10^{-3}$ & $2.789 \pm 4.771 \times 10^{-2}$ & $\mathrm{p}=0.61$ \\
OB XPA & $3.411 \pm 1.919 \times 10^{-3}$ & $2.868 \pm 1.460 \times 10^{-3}$ & $\mathrm{p}=0.42$ \\
\hline
\end{tabular}

Abbreviations: OB, olfactory bulb; RT-PCR, real-time polymerase chain reaction. The amount of COX2, IL-1ß, L1G1, OGG1, and XPA cDNA in each sample was normalized to the amount of GAPDH cDNA, yielding an index (molecules per attomol GAPDH rRNA) proportional to the relative abundance of each mRNA in each sample. Values are expressed as molecules/attomol GAPDH. Values are mean \pm SD 


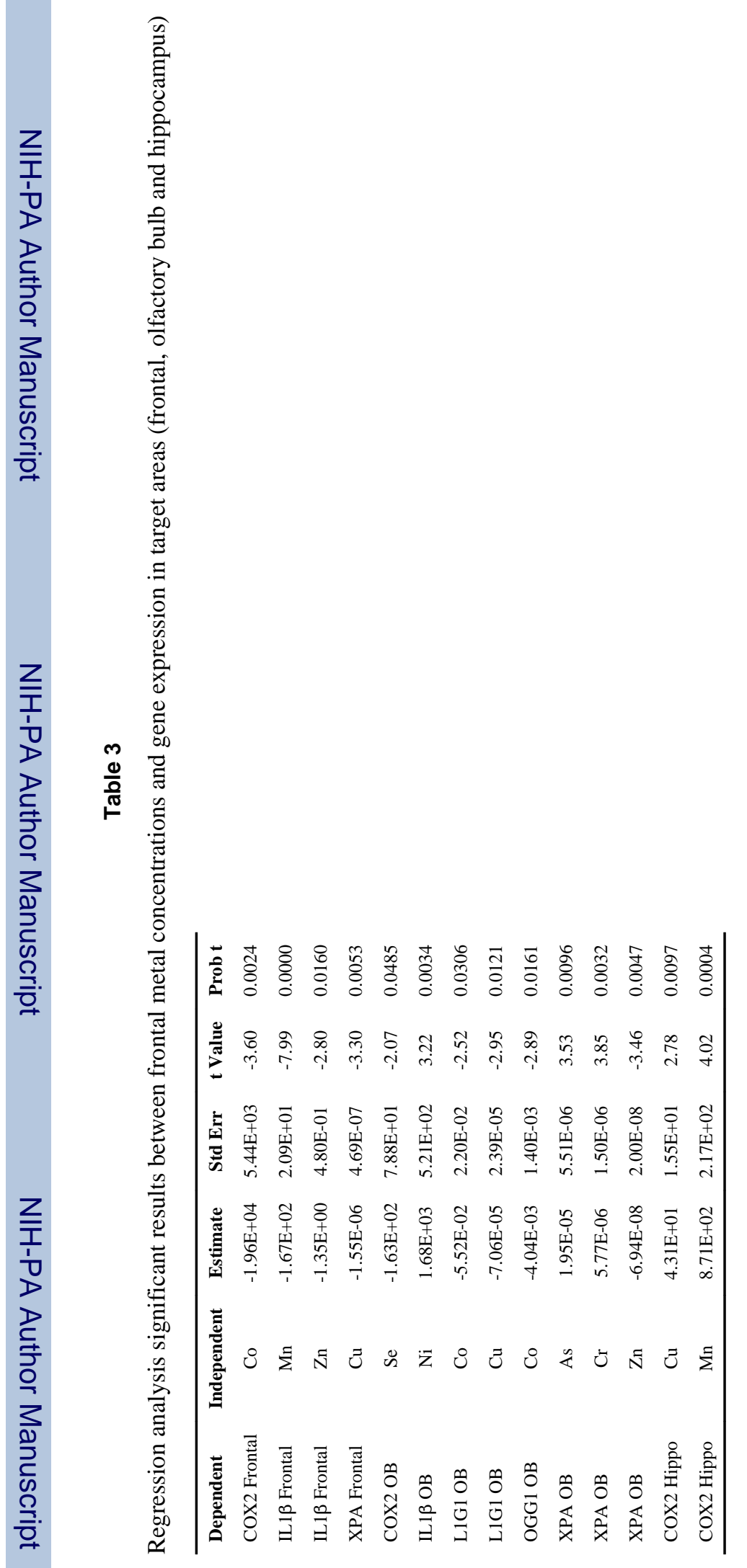

Exp Toxicol Pathol. Author manuscript; available in PMC 2014 July 01. 
Table 4

Regression analysis between Age and Metal Frontal Lobe Concentrations in Mexico City residents

\begin{tabular}{lcccc}
\hline Metal & Estimate & Std Err & t Value & Prob t \\
$\mathrm{As}$ & $3.36 \mathrm{E}-01$ & $4.68 \mathrm{E}-01$ & 0.72 & 0.4785 \\
$\mathrm{Co}$ & $1.90 \mathrm{E}-01$ & $6.77 \mathrm{E}-02$ & 2.80 & 0.0080 \\
$\mathrm{Cr}$ & $3.34 \mathrm{E}+00$ & $2.72 \mathrm{E}+00$ & 1.23 & 0.2258 \\
$\mathrm{Cu}$ & $5.10 \mathrm{E}+01$ & $4.19 \mathrm{E}+01$ & 1.22 & 0.2303 \\
$\mathrm{Mn}$ & $2.83 \mathrm{E}+00$ & $1.07 \mathrm{E}+00$ & 2.65 & 0.0114 \\
$\mathrm{Ni}$ & $-6.63 \mathrm{E}-02$ & $3.17 \mathrm{E}-01$ & -0.21 & 0.8353 \\
$\mathrm{~Pb}$ & $4.01 \mathrm{E}-01$ & $8.01 \mathrm{E}-01$ & 0.50 & 0.6192 \\
$\mathrm{Se}$ & $1.76 \mathrm{E}+01$ & $6.28 \mathrm{E}+00$ & 2.81 & 0.0078 \\
$\mathrm{~V}$ & $7.73 \mathrm{E}-01$ & $4.87 \mathrm{E}-01$ & 1.59 & 0.1202 \\
$\mathrm{Zn}$ & $1.22 \mathrm{E}+02$ & $9.45 \mathrm{E}+01$ & 1.29 & 0.2037 \\
\hline
\end{tabular}

